GRASAS Y ACEITES 72 (4)

October-December 2021, e433

ISSN-L: 0017-3495

https://doi.org/10.3989/gya.0553201

\title{
Bioactivity of betulinic acid nanoemulsions on skin carcinogenesis in transgenic mice K14E6
}

\author{
-B. Agame-Lagunes ${ }^{\mathrm{a}}, \oplus \mathrm{M}$. Alegria-Rivadeneyra ${ }^{\mathrm{a}}, \oplus \mathrm{A}$. Alexander-Aguilera ${ }^{\mathrm{b}, \bowtie}, \oplus \mathrm{R}$. Quintana-Castro ${ }^{\mathrm{b}}$,

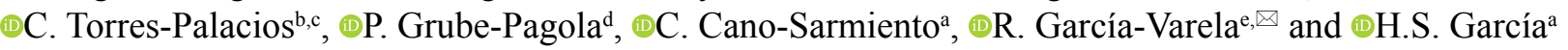 \\ ${ }^{a}$ Unidad de Investigación y Desarrollo en Alimentos, Tecnológico Nacional de México/IT de Veracruz. Calz. Miguel Ángel de Quevedo \\ 2779. Veracruz, Ver. 91897, México. \\ bUniversidad Veracruzana, Facultad de Bioanálisis. Iturbide S/N, Col. Centro, Veracruz, Ver. 91700, México. \\ 'Universidad Cristóbal Colón, División Académica de Ciencias de la Salud, Carretera Veracruz-Medellín s/n. Boca del Rio, Ver. 94271, México. \\ dUniversidad Veracruzana, Instituto de Investigaciones Médico Biológicas, Iturbide s/n, Veracruz, Ver. 91700, México \\ 'Tecnológico de Monterrey, Escuela de ingeniería y Ciencias, Av. General Ramón Corona 2514, Nuevo México 45138, Zapopan, Jalisco, México \\ ${ }^{\circledR}$ Corresponding authors: aalexander@uv.mx; rebecagv@tec.mx
}

Submitted: 07 May 2020; Accepted: 21 October 2020; Published online: 02 January 2022

SUMMARY: Alternative therapies for cancer treatment have been developed using bioactive compounds such as betulinic acid (BA). The objective of this study was to investigate the bioactivity of BA in its free form and compare it with its nano-encapsulated form under a skin carcinogenesis protocol in a genetically modified murine model. K14E6 and FVB mice were divided into four groups to be treated with free BA and with betulinic acid nanoemulsion (BANE). Lecithin enriched with medium chain fatty acids (MCFAs) was employed as an emulsifier to prepare the nanoemulsions with a mean droplet size of $40 \mathrm{~nm}$. Skin tumors were induced by exposure to DMBA and TPA directly to the transgenic mice. Tumor development was completely inhibited by BANE and by $70 \%$ with free BA. This was validated by histological sections and the gene expression of the Cdk4 and Casp8 genes.

KEYWORDS: Betulinic acid; Medium chain fatty acids; Mice; Modified lecithin; Nanoemulsion; Skin tumors

RESUMEN: Bioactividad de nanoemulsiones de ácido betulínico en la carcinogénesis de la piel en ratones transgénicos K14E6. Terapias alternativas para el tratamiento del cáncer han sido desarrolladas usando compuestos bioactivos como el ácido betulínico (AB). El objetivo de este estudio fue investigar la bioactividad del AB en su forma libre, y compararlo con su forma nano-encapsulada, bajo un protocolo de carcinogénesis cutánea en un modelo murino modificado genéticamente. Los ratones K14E6 y FVB fueron asignados a cuatro grupos tratados con $\mathrm{AB}$ libre y con nanoemulsión de ácido betulínico (NEAB). La lecitina enriquecida con ácidos grasos de cadena media (AGCM) se empleó como emulsionante para preparar las nanoemulsiones con un tamaño medio de gota de $40 \mathrm{~nm}$. Los tumores de piel fueron inducidos por la exposición a DMBA y TPA directamente a los ratones transgénicos. El desarrollo del tumor fue completamente inhibido por las NEAB y en $70 \%$ por el AB libre. Esto fue validado por las secciones histológicas y la expresión de los genes Cdk4 y Casp8.

PALABRAS CLAVE: Ácido betulínico; Ácidos grasos de cadena media; Lecitina modificada; Nanoemulsión; Ratones; Tumores de la piel

Citation/Cómo citar este artículo: Agame-Lagunes B, Alegria-Rivadeneyra M, Alexander-Aguilera A, Quintana-Castro R, TorresPalacios C, Grube-Pagola P, Cano-Sarmiento C, Garcia-Varela R, García HS. 2021. Bioactivity of betulinic acid nanoemulsions on skin carcinogenesis in transgenic mice K14E6. Grasas Aceites 72 (4), e433. https://doi.org/10.3989/gya.0553201

Copyright: ${ }^{0} 2021 \mathrm{CSIC}$. This is an open-access article distributed under the terms of the Creative Commons Attribution 4.0 International (CC BY 4.0) License. 


\section{INTRODUCTION}

Cancer is one of the main causes of death worldwide. It is characterized by a deregulation of cell growth and proliferation (Diaz-Cano, 2015). It is estimated that by 2025 the incidence per year will reach 19.3 million (Bishayee and Block, 2015) and it has been documented that melanoma-type skin cancer is associated with higher morbidity in Latino populations (Rodríguez et al., 2018). In addition, the increase in the incidence of skin cancer is mainly attributable to prolonged periods of sun exposure. Firsthand treatments continue to be mainly radiotherapy, chemotherapy, surgery, hormone therapy and targeted therapies. However, these strategies have proven to show adverse secondary side-effects such as damage to adjacent tissues. Because of its incidence, finding alternative therapies to treat it is of utmost importance (Pejin et al., 2014). The use of natural compounds as a complementary therapy has attracted great interest in the prevention and treatment of cancer and since several biochemical and genetic mechanisms are involved in the development of cancer, it is necessary to investigate the different pathways in order to propose novel treatments (Palumbo et al., 2013; Pejin et al., 2013). Betulinic acid (3ß, LUP-hydroxy-20 (29) -en28-oic) is a triterpene isolated mainly from the bark of the white birch tree (Betula alba), to which several therapeutic properties have been attributed, with the most promising being its antitumoral effect. It has been reported to induce apoptosis in melanoma cells since 1995 (Fulda and Kroemer, 2009) by the loss of mitochondrial membrane potential through the release of cytochrome C, smac/DIABLO, the activation of caspases 3 and 9 by APAF1 binding among other proteins and, by causing DNA damage (Ali-Seyed et al., 2016). However, there are insufficient studies to explain the interaction between BA and cell cycle progression (Chintharlapalli et al., 2011). It has also been reported that $\mathrm{BA}$ induces cell cycle arrest in the $\mathrm{G} 2 / \mathrm{M}$ phase by regulation of the Hiwi protein and Cyclin B (Yang et al., 2010). BA has very little pharmacokinetic value due to its low aqueous solubility $(\sim 21 \mu \mathrm{g} / \mathrm{mL})$ (Saneja et al., 2018). Nanotechnologybased drug delivery systems in cancer therapy have been demonstrated to be suitable for the administration of lipophilic compounds by improving distribution capacity (Jabir et al., 2012). Nanoemulsions are characterized by their droplet size ranging between 20-200 nm (Kabri et al., 2011). The main focus of this research is based on assessing the effects of free and nanoencapsulated BA on a skin cancer mouse model.

\section{MATERIALS AND METHODS}

Phospholipase $\mathrm{PLA}_{1}$ Lecitase $^{\circledR}$ Ultra was provided by NOVO (Salem, VA); Duolite A568 support was a gift from Rohm \& Haas (Barcelona, Spain). Phosphatidylcholine (PC) (95\% PC soy) was purchased from Shenyang Tianfeng Bioengineering Technology Co. (Shenyang, Liaoning, China). Free medium-chain fatty acids were obtained from the saponification of commercial Original Thin $\mathrm{Oil}^{\circledR}$ (Dover, Idaho). Betulinic acid was purchased from Indofine Chemicals (Hillsborough, NJ). Fifteen K14E6 transgenic mice, descendent from the original mice provided by Prof. Patricio Gariglio, and five control FVB mice were provided by the animal facility of the Universidad Cristóbal Colón in Veracruz. The iTaqTM Universal SYBR Green OneStep (BIO RAD, Hercules, CA) Kit was employed for the RT-PCR assay.

\subsection{Obtaining free medium-chain fatty acids (MCFAs)}

$100 \mathrm{~g}$ of Original Thin $\mathrm{Oil}^{\circledR}$ were added to $40 \mathrm{~g}$ of $\mathrm{NaOH}$ dissolved in $100 \mathrm{~mL}$ of distilled water and 300 $\mathrm{mL}$ of ethanol. The mixture was heated and stirred for 30 minutes before it was transferred to a $2 \mathrm{~L}$ separatory funnel. $200 \mathrm{~mL}$ of distilled water were added and the unsaponifiable matter was extracted with $300 \mathrm{~mL}$ of hexane. The aqueous phase was transferred to another separatory funnel, to which concentrated $\mathrm{HCl}$ was added until a $\mathrm{pH}$ value of 1.0 was reached. The lower layer was discarded; then $400 \mathrm{~mL}$ of hexane and $200 \mathrm{~mL}$ of distilled water were added. The mixture was shaken, and the lower layer was discarded. The organic phase was filtered through a bed of anhydrous sodium sulfate and passed through a silica gel column. Hexane was then removed under vacuum in a rotary evaporator at $40^{\circ} \mathrm{C}$.

\subsection{Obtaining the emulsifier}

An acidolysis reaction was performed using phospholipase PLA 1 immobilized on Duolite A568 (Ochoa-Flores et al., 2017). Briefly, the reaction mixture consisted of PC and free MCFAs in a 1:15 molar ratio. The immobilized enzyme was added at $12 \%$ of the total substrate weight. The reaction mixture was incubated in an orbital shaker at $50{ }^{\circ} \mathrm{C}$ 
and $300 \mathrm{rpm}$ for 12 hours. Incorporation of MCFAs into PC was determined by alkaline methylation using $1 \mathrm{M}$ sodium methoxide. Fatty acid methyl esters were extracted with hexane and $1 \mu \mathrm{L}$ of the extract was injected into a Hewlett-Packard 6890 gas chromatograph equipped with a flame ionization detector (FID), and a HP-INNOWAX (60 $\mathrm{m} X 0.25 \mathrm{~mm}$ X $0.25 \mathrm{~mm}$ ) capillary column. The method consisted of $50{ }^{\circ} \mathrm{C}$ as initial temperature for 1 minute, followed by a ramp of $7{ }^{\circ} \mathrm{C}$ per minute to $200{ }^{\circ} \mathrm{C}$ then held for 16 minutes. Total running time was 35 minutes. The injection port was set at $200{ }^{\circ} \mathrm{C}$ and the detector at $230{ }^{\circ} \mathrm{C}$. Yield was determined by HPLC analysis. Aliquots were taken from samples and diluted in ethanol to a $10 \mathrm{mg} / \mathrm{mL}$ final concentration; $50 \mu \mathrm{L}$ were injected into the HPLC system consisting of a binary pump (Waters 1525), an automatic injector (Waters 717plus) and a UV-Visible detector (Waters 2487). An Alltech normal phase Econosil Silica $(5 \mu \mathrm{m}, 250$ x $4.6 \mathrm{~mm})$ was used at $40{ }^{\circ} \mathrm{C}$. The mobile phase consisted of acetonitrile/methanol/phosphoric acid (130:5:1.5 $\mathrm{v} / \mathrm{v} / \mathrm{v}$ ) at an isocratic flow rate of $1.8 \mathrm{~mL} / \mathrm{min}$.

\subsection{Purification of the emulsifier}

A $460 \mathrm{~mm} \times 57 \mathrm{~mm}$ glass chromatographic column packed with $600 \mathrm{~g}$ of silica gel with a 60-200mesh size and a pore diameter of $150 \AA$ was used. The mobile phase consisted of chloroform to remove the fatty acids, and chloroform/methanol (65:35) to separate the modified PC (Vikbjerg et al., 2006).

\subsection{Preparation and characterization of nanoemul- sions (NE)}

The methodology of Cavazos-Garduño et al. (2015) was followed with slight modifications: 1 $\mathrm{g}$ of PC was dissolved in $6.0 \mathrm{~g}$ of water and $2.5 \mathrm{~g}$ of glycerol, by stirring for $5 \mathrm{~min}$; subsequently 0.5 $\mathrm{g}$ of medium-chain oil containing $25 \mathrm{mg}$ of BA were added and shaken for $3 \mathrm{~min}$; the two phases were combined and ultrasonicated for $5 \mathrm{~min}$ in an Aquawave 9376 ultrasonic bath (Barnstead/ Labline). To produce a coarse emulsion, the mixture was homogenized for $3 \mathrm{~min}$ at 20,000 rpm using an Ultraturrax T25 homogenizer, subsequently submitted to ultrasonication at a $20 \%$ duty cycle amplitude in a Branson Digital Sonicator S-450D for 4 minutes to obtain the $\mathrm{O} / \mathrm{W}$ NE. For the characterization of nanoemulsions, a Nano-ZS90 dynamic light scattering device (Malvern Instruments Inc., Worcestershire, UK) was employed.

\subsection{Betulinic acid nanoemulsions (BANE) under skin carcinogenesis protocol}

15 K14E6 (genetically modified) and 5 FVB mice, at 6 weeks of age (25-30 g) were used and maintained in a controlled environment at $24-26^{\circ} \mathrm{C}$, with a relative humidity of $60 \%$ and $12 / 12 \mathrm{~h}$ light/dark cycles. The mice were divided into four groups. Group 1 was the healthy control (FVB), group 2 was the sick control, group 3 were mice treated with free betulinic acid (Free BA) and group 4 were mice treated with BANE. Every treatment was orally administered twice a week at a rate of $50 \mathrm{mg} / \mathrm{kg}$ body weight (Das et al., 2016). Skin tumors were induced in the previously shaven dorsal area. During the first week a single topical dose of DMBA (7,12-dimethylbenzanthracene) was applied at a concentration of $25 \mathrm{nmol}$ in $0.2 \mathrm{~mL}$ acetone. The second week the animals rested. From the third to the eighth week, two doses of TPA (12 o-tetradecanoyl-phorbol-13-acetate) were applied at a concentration of $6.8 \mathrm{nmol}$ in $0.2 \mathrm{~mL}$ acetone. Growths were considered as tumors when they were at least 1 $\mathrm{mm}$ diameter; their surface area was calculated by the following formula: $\mathrm{A}=(\pi)(\mathrm{R} 1)(\mathrm{R} 2)$.

\subsection{Ethics statement}

All animal studies were carried out with the approval of the Instituto Tecnológico de Veracruz (protocol CEI-ITVER/023/2015) and conducted under the National Research Council Guide for the Care and Use of Laboratory Animals, $8^{\text {th }}$ Edition (2011).

\subsection{Histological evaluation}

Cross-sections of the samples with $5 \mu \mathrm{m}$ thickness were obtained by means of a sliding microtome (Microm International GmBH, Walldorf, Germany) for further staining with hematoxylin and eosin dye.

\section{8. qRT-PCR}

RNA extraction was performed according to the Trizol reagent protocol (Sigma-Aldrich, Mexico City). RNA was quantified by spectrometry in a NanoDrop ${ }^{\mathrm{TM}}$ set at 260 and $280 \mathrm{~nm}$. RT-PCR primer sequences used were for Cyclin-dependent kinase (CdK4) F: 5'-TTT CTA AGC GGC CTG GAT TTT-3' R: 5'CCA GCT TGA CGG TCC CAT TA-3', Caspase 8 
(Casp8) F: 5'-GGC AGG CTT CGA GCA ACA-3' R: 5'-CGT AGC CAT TCC CAG CAG AA-3' and glyceraldehyde phosphate dehydrogenase (GAPDH) as the housekeeping gene F: 5'-ATG TGT CCG TCG TGG ATC TGA-3' R: 5'-TTG AAG TCG CAG GAG ACA ACC T-3' (Mendoza-Villanueva et al., 2008) to be performed on a RT-PCR using the StepOne ${ }^{\mathrm{TM}}$ software and applying the $2^{-\Delta \Delta C T}$ method to calculate the relative quantitation. The iTaqTM Universal SYBR ${ }^{\circledR}$ Green One-Step kit (BIO RAD) was employed.

\subsection{Statistical analyses}

The statistical analysis of the data was made by analysis of variance (ANOVA) and Tukey's means comparison test, using the statistical package Minitab v. 18; a value of $\mathrm{p}<0.05$ was considered significant. The student $t$-test was used to calculate the levels of significance in the gene expression analysis. Values of $p$ less than 0.05 were considered statistically significant.

\section{RESULTS}

\subsection{Incorporation of free medium-chain fatty acids (MCFAs) to PC}

Free fatty acids were obtained as a product of the saponified medium-chain oil with a composition of $68.93 \%$ caprylic acid (C8:0) and $30.77 \%$ capric acid (C10:0). Adsorption of the enzyme onto the support was quantified by Bradford obtaining an immobilization of $64 \%$, with $46 \mathrm{mg}$ of protein adsorbed/g of support from an initial suspension of $75 \mathrm{mg}$ of protein/g. Figure 1 shows the kinetics of

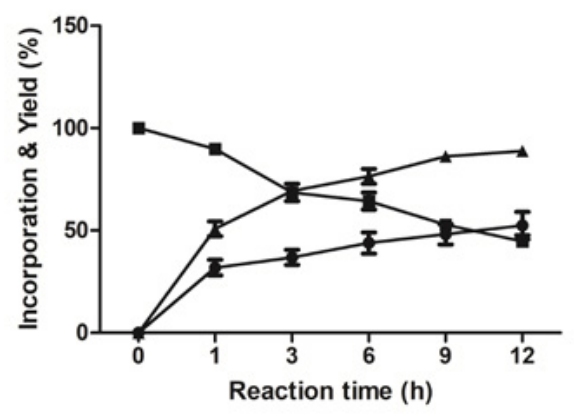

\footnotetext{
- MCFAs Incorporation $\quad \star$ Modified PC Yield $\rightarrow$ PC Yield

FIGURE 1. Incorporation of MCFAs, yield of PC and modified $\mathrm{PC}$ by acidolysis with $\mathrm{PLA}_{1}$; Molar ratio of substrates $(\mathrm{PC} /$ MCFAs) of $1: 15$ and $12 \%$ enzyme concentration at $50{ }^{\circ} \mathrm{C}$. $\mathrm{PC}=$ phosphatidylcholine, MCFAs= medium-chain fatty acids. Tukey's test was used to compare averages in the incorporation of MCFAs, PC Yield and modified PC Yield. Each data point represents the mean of three replicates and their SD.
}

the incorporation of MCFAs to PC (59\%), the yield of PC (47\%) and modified PC (86\%) during $12 \mathrm{~h}$ of reaction.

\subsection{Separation of modified phospholipids by solid phase extraction}

$120 \mathrm{~g}$ of free fatty acids and $22 \mathrm{~g}$ of modified PC were recovered. The composition of fatty acids from modified PC used as emulsifier for BANE can be observed in Table 1.

TABLE 1 . Fatty acid composition (molar \%) of native and modified $\mathrm{PC}$ obtained from column chromatography separation of the $\mathrm{PLA}_{1^{-}}$ catalyzed acidolysis reaction products.

\begin{tabular}{cccc}
\hline Fatty Acid & $\begin{array}{c}\text { Native PC } \\
(\%)\end{array}$ & $\begin{array}{c}\text { Modified PC } \\
(\%)\end{array}$ & P \\
\hline C8:0 & ND & $42.66 \pm 0.62$ & \\
C10:0 & ND & $16.42 \pm 1.59$ & \\
C12:0 & ND & ND & \\
C14:0 & $1.18 \pm 1.07$ & ND & \\
C16:0 & $12.16 \pm 1.56$ & $2.19 \pm 0.23$ & 0.008 \\
C16:1 & $2.45 \pm 0.59$ & ND & \\
C18:0 & $3.83 \pm 0.50$ & $0.09 \pm 0.05$ & 0.006 \\
C18:1 (9) & $12.12 \pm 0.55$ & $0.65 \pm 0.20$ & 0.001 \\
C18:1 (7) & ND & $4.62 \pm 0.55$ & \\
C18:2(6) & $60.83 \pm 2.70$ & $27.73 \pm 2.39$ & 0.001 \\
C18:3 (3) & $6.36 \pm 0.25$ & $3.20 \pm 0.31$ & 0.001 \\
C20:0 & $0.67 \pm 0.18 *$ & ND & \\
Total MCFAs & & 59.08 & \\
\hline
\end{tabular}

PC was modified under the following conditions: PC and MCFAs in a molar ratio $1: 15,12 \%$ of enzyme immobilized $\mathrm{PLA}_{1}$ on Duolite A568 under 12 hours reaction. PC-Phosphatidylcholine, PLA1-Phospholipase A1, MCFAs-Medium chain fatty acids. Values are reported as means \pm SD of the triplicate determinations $(\mathrm{P}<0.05)$ by two-sample T-test. ND $=$ not detected.

\subsection{Preparation and characterization of nanoemul- sions (NE) stabilized with modified PC}

To compare the droplet size, nanoemulsions were structured with either native PC or modified PC; both systems contained BA and produced nanometer droplet sizes (Table 2).

\subsection{Effect of BANE on skin carcinogenesis}

In the sick control group, the number of tumors were $7.33 \pm 5.8$. In the group with the carcinogens and free BA, the mean number of tumors was 2.25 \pm 1.25 , which represents a $70 \%$ reduction, as shown in Figure 2. Finally, in the group treated with the 
TABLE 2. Characterization of NE with native and modified PC as emulsifier.

\begin{tabular}{cccc}
\hline PC & $\begin{array}{c}\text { Droplet size } \\
(\mathbf{n m})\end{array}$ & PDI & $\begin{array}{c}\zeta \text { Potential } \\
(\mathbf{m v})\end{array}$ \\
\hline Unmodified & $88 \pm 0.97^{\mathrm{a}}$ & $0.10 \pm 0.036^{\mathrm{a}}$ & $-3.8 \pm 0.5^{\mathrm{a}}$ \\
Modified & $40 \pm 1.65^{\mathrm{b}}$ & $0.14 \pm 0.018^{\mathrm{a}}$ & $-15 \pm 1.7^{\mathrm{b}}$ \\
\hline
\end{tabular}

Preparations made with $10 \%$ phosphatidylcholine or modified phosphatidylcholine, $25 \%$ glycerol in the aqueous phase and $25 \mathrm{mg}$ of BA/g of NE and $5 \%$ of MCT in the oil phase. NE- Nanoemulsion, PC- Phosphatidylcholine, PDI- Polydispersity Index. Tukey test was used to evaluate mean difference $(n=3)$. Means that do not share a letter are significantly different $\mathrm{P}=0.0001$.

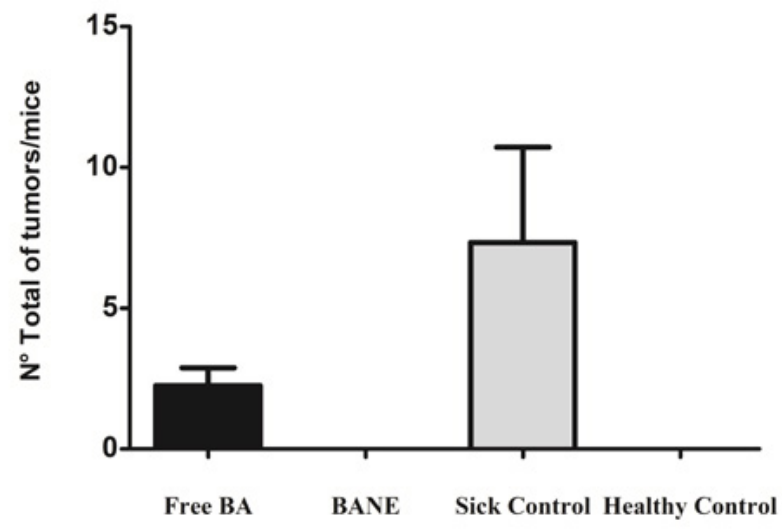

FIGURE 2. Effect of free BA and BANE on skin tumorigenesis of K14E6 mice with DMBA ( $25 \mathrm{nmol} / 0.2 \mathrm{~mL}$ acetone) and TPA $(6.8 \mathrm{nmol} / 0.2 \mathrm{~mL}$ acetone) for eight weeks. One-way ANOVA, $\mathrm{P}=0.007$. Data points are mean values from five replicates; errors bars represent the SD.

carcinogens and BANE, no skin tumorigenesis was observed. In Table 3, the average tumor surface areas by groups are depicted compared with the healthy control group (FVB).

TABLE 3. Effect of BA on tumor surface area of all groups $\left(\mathrm{mm}^{2}\right)$

\begin{tabular}{cccc}
\hline $\begin{array}{c}\text { Healthy } \\
\text { control (FVB) }\end{array}$ & $\begin{array}{c}\text { Sick } \\
\text { Control N/T }\end{array}$ & $\begin{array}{c}\text { Free BA } \\
\text { group }\end{array}$ & BANE group \\
\hline 0.00 & $15.62 \pm 0.78 \mathrm{~A}$ & $14.92 \pm 0.97 \mathrm{~A}$ & $0.00 \pm 0.00 \mathrm{~B}$ \\
\hline
\end{tabular}

Data represent the mean $\pm \mathrm{SD}$ on each treated group $(\mathrm{n}=5)$,

One-way ANOVA/Tuckey $P=0.002$. Free BA-Free betulinic acid, BANE-betulinic acid nanoemulsión.

\subsection{Histological evaluation}

Figure 3 illustrates the histological results of all 4 treatment groups: (A) healthy control group (FVB), a normal cell architecture is observed in the epidermis, dermis, subcutaneous tissue and appendages. The tissue

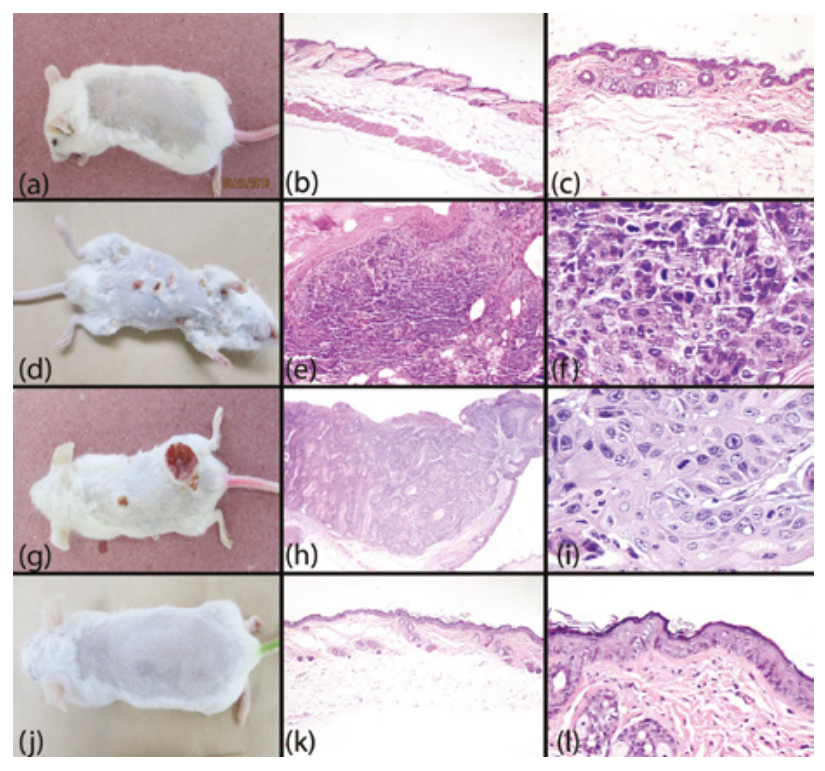

FIGURE 3. (a) Macroscopic appearance of healthy control; (b) histological dissection of skin without histological alterations (H\&E, $2 \mathrm{x})$; (c) histological dissection without alterations in hair follicles and sebaceous glands (H\&E, 5x); (d) sick control macroscopic appearance of mouse with multiple epidermoid carcinomas; (e) infiltrating epidermoid carcinoma with areas of surface keratinization (H\&E, 5x); (f) neoplastic cells with moderate cytoplasm, pleomorphic nuclei of granular chromatin and abundant mitoses (H\&E, 40x); (g) macroscopic aspect of mice treated with free BA,

shows two neoplastic lesions in the dorsal region, the largest of which is ulcerated; (h) neoplastic lesion corresponds to infiltrating epidermoid carcinoma with differentiation regions (H\&E, 2x); (i) morphological appearance of neoplastic cells with broad keratinizing cytoplasm, large nuclei with dispersed granular chromatin, note also mitosis; (j) macroscopic aspect of mice treated with BANE, does not show neoplasia; (k) histological cut of skin without histological alterations (H\&E, 2x); (1) histological dissection with slight chronic inflammatory infiltrate in the dermis $(\mathrm{H} \& \mathrm{E}, 10 \mathrm{x})$.

of the sick control group (only treated with DMBA/ TPA) (D), had moderately differentiated squamous keratinizing carcinoma development, composed entirely of atypical squamous epithelial cells with intense keratin production, neoplastic cells with irregular nuclei and abundant mitosis. In the group treated with free BA $(\mathrm{G})$, the mice developed a keratinizing epidermoid carcinoma. The group treated with BANE (J), showed normal skin architecture without tumor lesions of any type and regular morphology was observed. The epidermal structure of the BANE-treated group was similar to the healthy control group.

\subsection{Gene expresión}

The gene expression analysis (Figure 4) showed similar statistical RQ values for each treatment group: Cdk4 and Casp8. In the free BA and BANE 


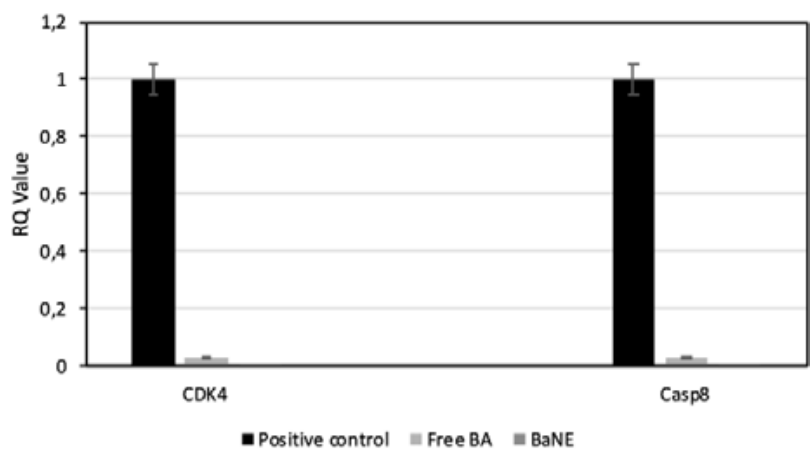

Figure 4. Relative Quantitation values for Cdk4 and Casp8 gene expression. Student $t$-test was employed to calculate the levels of significance, and $\mathrm{P}<0.05$ was considered statistically significant. The data points represent the mean of five replicates and the error bar is the SD.

groups, differences were evident when compared to the healthy and sick control groups; however, there was no difference between their signaling pathway level. RQ values were 0.03 and 0.0002 for $\mathrm{Cdk} 4$ and Casp8, respectively; the values for free BA and BANE were 0.04 and 0.0005 , respectively. Cdk4 and Casp8 expression levels were reduced when free BA and BANE were supplied, suggesting that the mechanism of action of this compound may influence the cyclin-dependent pathway and repressed $\mathrm{Rb} 1$.

\section{DISCUSSION}

This investigation describes the bioactivity of free BA compared to its nanoemulsified form as well as the advantage of the enzymatic modification that was carried out through the use of phospholipase PLA (Ochoa-Flores et al., 2017). Our results showed an increase in the modification of PC with MCFAs under the optimal conditions mentioned in the results section. Recent research showed that the enzymatic modification of phospholipids by $\mathrm{PLA}_{1}$ reached a significant level after $24 \mathrm{~h}$ of reaction (Li et al., 2014). The choice of oil is an important variable, since it directly affects the NE droplet size, along with its chemical and optical properties (Cavazos-Garduño et al., 2015). Stability increases with small sizes by avoiding gravitational segregation, flocculation by Brown's movement and greater system transparency; their bio-accessibility has been increased in in vitro systems when using O/W NE (Salvia-Trujillo et al., 2013). It has been reported that using polylactide-coglycolide-monomethoxy polyethylene glycol nanoparticles containing BA, where $147 \mathrm{~nm}$ globule sizes were obtained, increased its antitumor activity by up to 7 times in an Erlich carcinoma model (Saneja et al., 2017). The hepatoprotective activity of BA in nanoemulsions with sizes of $150.3 \mathrm{~nm}$, a PDI of 0.192 , a Z-potential of $-10.2 \mathrm{mV}$ has been reported, together with an increase in its solubility when dispersed in olive oil in Wistar rats with $\mathrm{CCl}_{4}$ as a toxic agent (Harwansh et al., 2017). In the same way, using chicken embryos, the anti-angiogenic effect of nanoemulsions with a globule size of $145 \mathrm{~nm}$ and a Z-potential of $-39.1 \mathrm{mV}$ has been documented (Dehelean et al., 2011). In this study, particle sizes of $40 \mathrm{~nm}$, a PDI of 0.14 , and a Z-potential of $-15 \mathrm{mV}$ were attained. The reduction in particle size increased the superficial area, enhancing the absorption capacity of the bioactive by biological membranes such as the intestinal lining and/or skin; i.e., it improved the transport, exposure, and activity of the encapsulated compound, evidencing that a minimum amount can be employed to exert its therapeutic activity. The use of carrier systems has opened a field to investigate the different routes of the carcinogenesis process in murine models. This has been envisioned for the development of drugs that use natural compounds with low bioavailability, such as in the case of BA. In a research regarding skin damage monitoring, the anti-angiogenic process and the damage caused to blood vessels by TPA and DMBA exposure to $\mathrm{BALB} / \mathrm{c}$ mice were described; betulin was used for 12 weeks and produced a reduction in blood vessels; and no tumor development was observed (Dehelean et al., 2011). When evaluating BA (both topic and oral $\mathrm{NE}$ ) in $\mathrm{C} 57 \mathrm{BL} / 6 \mathrm{~J}$ mice, with a liver implanted with B6 melanoma cells, a decrease in metastasis was found to be significant compared to the non-treated group (Ciurlea et al., 2010). When a complex of cyclodextrin with BA $(100 \quad \mathrm{mg} / \mathrm{kg})$ was intraperitoneally administered in an in vivo melanoma model (C57BL/6J) for 21 days, the tumor volume decreased from 300 to $150 \mathrm{~mm}^{3}$. However, the administration method, even though it was effective, caused significant pain and distress to the animal. Because of the BA structure, it can be metabolized and degraded, thereby releasing the compound before the target cells could be reached (Soica et al., 2014). In this research, we prepared a nanoemulsion system to be administered orally, without causing harm to the animal. Moreover, it was formulated with nutraceutical materials that provide additional health benefits, such as MCFAs and lecithin. These are 
important components in the architecture of cell membranes which increase the bioavailability of the bioactive compound and enhance its intestinal absorption by enterocytes, or it is absorbed directly through the lymphatic system. One of the advantages of our nanoemulsified system is the globule size of $<$ $200 \mathrm{~nm}$, allowing better absorption of the compound through cellular membranes. Also, an additional benefit of using MCFAs is the increased bioaccessibility of lipophilic compounds; unlike longchain fatty acids, MCFAs are more easily dispersed in aqueous phases and confer better protection to the nanoemulsion against lipolytic enzymes; they can also form micelles in the intestine for the solubilization of hydrophobic bioactive compounds. Furthermore, it is hypothesized that the chemical structure of BA resembles cholesterol in terms of its insertion into the plasmatic membrane. It was estimated that BA changed cell membrane fluency, and thereby modulated the signaling pathway associated with membrane microdomains, translocated certain receptors, and inhibited cell proliferation and migration (Chen et al., 2016). It has also been proposed that its antitumor effect is caused by the inhibition of tumor angiogenesis, promoting a decrease in the supply of nutrients and oxygen to potential tumor formations; therefore, a decrease in growth rate was probably caused by low rates of cell necrosis (Aisha et al., 2012), but also increased cellular apoptosis, loss of membrane potential and cell cycle arrest (Saneja et al., 2017). The specific cytotoxicity of BA has been previously found in neuroblastoma and glioblastoma cell lines (Thurnher et al., 2003); however, the mechanism is not yet fully understood. Implicated genes in skin and cervical cancer have been outlined to clarify these conditions and determine whether BA can be effective to counter it. In that study, Ccne 2 and $\mathrm{Cdk} 4$ were upregulated in skin cancer and showed no changes in cervical cancer. This suggested that the above genes were involved in these particular cancer types (Mendoza-Villanueva et al., 2008). It is important to note that the transgenic mouse model used in our project, K14E6, was designed to express E6 and E7 genes from Human Papilloma Virus (HPV) in skin, promoting the development of skin cancer; these genes were implanted in the embryo's ectoderm for their future expression. It has been reported that E6 inhibits p53, which is a tumor suppressor gene that regulates cell cycle by mediating $\mathrm{p} 21$. Additionally, E7 inhibits the expression of the retinoblastoma (RB) gene, another tumor suppressor gene that also regulates cell cycle. Under normal circumstances both p53 and RB cease cell division at the $\mathrm{G}_{1}$ phase by compromising $\mathrm{CDK}$ binding to Cyclins or by restricting DNA replication, respectively. This prevents the progression to the $S$ phase when there is a defect in cell division; conversely, in this case both genes were underexpressed, producing defective and uncontrolled proliferation of skin cancer cells. Casp8 expression levels were also found to be down-regulated in skin cancer, producing a favorable environment for the progression of this type of cancer. Attenuation of apoptosis attributed to Caspase inhibition has been suggested as one of the mechanisms for tumorigenesis onset in several types of cancer. In this manner, alteration in the Caspase expression might be a diagnostic biomarker for skin carcinoma. In our research, subjects treated with BA showed a significant decrease in Cdk4 when compared to our control untreated mice. This biomarker has been attributed as a target for the BA potential therapeutic effect by arresting the cell cycle at the $G_{1}$ phase as expected, as well as inducing apoptosis in melanoma cell lines. In this type of cancer Cdk4 is upregulated (Rieber and Rieber, 2006). It has been proposed that BA selectively activates the intrinsic apoptotic pathway in cancer cells by releasing cytochrome C, activating caspase 3 but not caspase 8 ; BA also regulates members of the Bcl-2 family and induces apoptosis in HeLa cells directly through this intrinsic pathway (Fulda, 2009; Gali-Muhtasib et al., 2015). BA bearing dephosphorylates the 3-kinase (PI3K)/ Akt phosphatidylinositol pathway by promoting cell viability in cancer cells, thereby repressing $\mathrm{Cdk}$ inhibitors p27 and the p21 cell cycle progression modulator. BA has proven to cease cell cycle progression in cell lines such as HeLa, at the G0/G1 phase through the inhibition of the PI3K/Akt pathway by incubating $30 \mu \mathrm{mol} / \mathrm{L}$ BA after 12 hours; in addition, it was found to contribute to mitochondrial apoptosis by membrane depolarization and increased Caspase activity (Xu et al., 2017).

The results described in this research suggest the enhanced beneficial effect of BA in its nanoemulsified form as a protector against skin carcinogenesis development and progression, as it can mediate multiple pathways as well as intervene 
in cell cycle regulation. It is still necessary to better clarify the interaction of BA in both its free and nanoencapsulated forms directly on the cell cycle, in order to explain the favorable response that was observed in this work, and thus be able to propose its use as a complementary therapy.

\section{CONCLUSIONS}

A complete inhibition of tumor development was observed in mice treated with BANE, confirming its antitumor activity in vivo, which is consistent with previous studies performed by several authors. Our data suggest a clear advantage of nanoencapsulating BA over its application in its free form. However, further studies remain to be carried out in order to precisely elucidate the molecular mechanisms, gene regulation, and cell cycle interference achieved by the BANE.

\section{ACKNOWLEDGMENTS}

The authors gratefully appreciate the financial support of the National Council for Science and Technology of México (CONACyT), through the grant 250784, and the graduate studies scholarship of authors Agame-Lagunes and Alegria-Rivadeneyra. We thankfully acknowledge Laura Bober, DVM, for her valuable assistance with animal handling.

\section{REFERENCES}

Aisha AFA, Abu-Salah KM, Ismail Z, Malik A, Abdul S. 2012. $\alpha$-Mangostin Enhances Betulinic Acid Cytotoxicity and Inhibits Cisplatin Cytotoxicity on HCT 116 Colorectal Carcinoma Cells. Molecules 17, 2939-2954. https://doi. org/10.3390/molecules17032939

Ali-Seyed M, Jantan I, Vijayaraghavan K, Bukhari SNA. 2016. Betulinic Acid: Recent Advances in Chemical Modifications, Effective Delivery, and Molecular Mechanisms of a Promising Anticancer Therapy. Chem. Biol. Drug Des. 87, 517-536. https://doi.org/10.1111/cbdd. 12682

Bishayee A, Block K. 2015. A broad-spectrum integrative design for cancer prevention and therapy: The challenge ahead. Semin. Cancer Biol. 35, S1-S4. https://doi.org/10.1016/j.semcancer.2015.08.002

Chen CL, Chen CY, Chen YP, Huang YB, Lin MW, Wu DC, Huang HT, Liu MY, Chang HW, Kao YC, Yang PH. 2016. Betulinic acid enhances
TGF- $\beta$ signaling by altering TGF- $\beta$ receptors partitioning between lipid-raft/caveolae and noncaveolae membrane microdomains in mink lung epithelial cells. J. Biomed. Sci. 23, 1-15. https:// doi.org/10.1186/s12929-016-0229-4

Cavazos-Garduño A, Ochoa Flores AA, Serrano-Niño JC, Martínez-Sanchez CE, Beristain CI, García HS. 2015. Preparation of betulinic acid nanoemulsions stabilized by $\omega-3$ enriched phosphatidylcholine. Ultrason. Sonochem. 24, 204-213. https://doi. org/10.1016/j.ultsonch.2014.12.007

Chintharlapalli S, Papineni S, Lei P, Pathi S, Safe S. 2011. Betulinic acid inhibits colon cancer cell and tumor growth and induces proteasome-dependent and -independent downregulation of specificity proteins (Sp) transcription factors. BMC Cancer 11, 371. https://doi.org/10.1186/1471-2407-11-371

Ciurlea SA, Dehelean CA, Ionescu D, Berko S, Csanyi E, Hadaruga DI, Ganta S, Amiji MM. 2010. A comparative study regarding melanoma activity of Betulinic acid on topical ointment vs. systemic nanoemulsion delivery systems. $J$. Agroaliment. Processes Technol. 16, 420-426.

Das J, Samadder A, Das S, Paul A, Rahman A, Khuda-Bukhsh AR. 2016. Nanopharmaceutical Approach for Enhanced Anti-Cancer Activity of Betulinic Acid in Lung-cancer Treatment via Activation of PARP: Interaction with DNA as a Target: -Anti-Cancer Potential of Nano-betulinic acid in Lung Cancer. J. Pharmacopunct. 19, 3744. https://doi.org/10.3831/KPI.2016.19.005

Dehelean CA, Feflea S, Ganta S, Amiji M. 2011. Antiangiogenic effects of betulinic acid administered in nanoemulsion formulation using chorioallantoic membrane assay. J. Biomed. Nanotechnol. 7, 31724. https://doi.org/10.1166/jbn.2011.1297

Diaz-Cano SJ. 2015. Pathological bases for a robust application of cancer molecular classification. Int. J. Mol. Sci. 16, 8655-8675. https://doi. org/10.3390/ijms 16048655

Fulda S. 2009. Betulinic acid: A natural product with anticancer activity. Mol. Nutr. Food Res. 53, 140 146. https://doi.org/10.1002/mnfr.200700491

Fulda S, Kroemer G. 2009. Targeting mitochondrial apoptosis by betulinic acid in human cancers. Drug Discov. Today 14, 885-890. https://doi. org/10.1016/j.drudis.2009.05.015

Gali-Muhtasib H, Hmadi R, Kareh M, Tohme R, Darwiche N. 2015. Cell death mechanisms 
of plant-derived anticancer drugs: Beyond apoptosis. Apoptosis. 20, 1531-1562. http://doi. org/10.1007/s10495-015-1169-2

Harwansh RK, Mukherjee PK, Biswas S. 2017. Nanoemulsion as a novel carrier system for improvement of betulinic acid oral bioavailability and hepatoprotective activity. J. Mol. Liq. 237, 361371. https://doi.org/10.1016/j.molliq.2017.04.051

Jabir NR, Tabrez S, AshrafGM, Shakil S, Damanhouri GA, Kamal MA. 2012. Nanotechnologybased approaches in anticancer research. Int. J. Nanomedicine 7, 4391-4408. https://doi. org/10.2147/IJN.S33838

Kabri TH, Arab-Tehrany E, Belhaj N, Linder M. 2011. Physico-chemical characterization of nano-emulsions in cosmetic matrix enriched on omega-3. J. Nanobiotechnology 9, 41. https://doi. org/10.1186/1477-3155-9-41

Li X, Chen JF, Yang B, Li DM, Wang YH, Wang WF. 2014. Production of structured phosphatidylcholine with high content of DHA/ EPA by immobilized phospholipase A1-catalyzed transesterification. Int. J. Mol. Sci. 15, 1524415258. https://doi.org/10.3390/ijms150915244

Mendoza-Villanueva D, Diaz-Chavez J, UribeFigueroa L, Rangel-Escareão C, Hidalgo-Miranda A, March-Mifsut S, Jimenez-Sanchez G, Lambert P, Garglio P. 2008. Gene expression profile of cervical and skin tissues from human papillomavirus type 16 E6 transgenic mice. BMC Cancer 8, 347. https:// doi.org/10.1186/1471-2407-8-347

Ochoa-Flores AA, Hernandez-Becerra JA, CavazosGarduñoA, Soto-RodriguezI, Sanchez-OteroMG, Vernon-Carter EJ, Garcia HS. 2017. Enhanced Bioavailability of Curcumin Nanoemulsions Stabilized with Phosphatidylcholine Modified with Medium Chain Fatty Acids. Curr. Drug Deliv. 14, 377-385. https://doi.org/10.2174/1567 2018136661609191428

Palumbo MO, Kavan P, Miller WH, Panasci L, Assouline S, Johnson N, Cohen V, Patenaude F, Pollak M, Jagoe RT, Batist G. 2013. Systemic cancer therapy: Achievements and challenges that lie ahead. Front. Pharmacol. 4 MAY, 1-9. https://doi.org/10.3389/fphar.2013.00057

Pejin B, Jovanovic K, Mojovic M, Savic A. 2013. New and Highly Potent Antitumor Natural Products from Marine-Derived Fungi: Covering the Period from 2003 to 2012. Curr. Top. Med.
Chem. 13 (21), 2745-2766. https://doi.org/10.21 74/15680266113136660197

Pejin B, Kojic V, Bogdanovic G. 2014. An insight into the cytotoxic activity of phytol at in vitro conditions. Nat. Prod. Res. 28 (22), 2053-2056. https://doi.org/10.1080/14786419.2014.921686

Rieber M, Rieber MS. 2006. Signalling responses linked to betulinic acid-induced apoptosis are antagonized by MEK inhibitor U0126 in adherent or 3D spheroid melanoma irrespective of p53 status. Int. J. Cancer 118, 1135-1143. https://doi. org/10.1002/ijc. 21478

Rodríguez VM, Shuk E, Arniella G, González CJ, Gany F, Hamilton JG, Gold GS, Hay JL. 2018. A qualitative exploration of Latinos' perceptions about skin cancer : The role of gender and linguistic acculturation. J. Cancer Educ. 32, 438-446. https:// doi.org/10.1007/s13187-015-0963-4.A

Salvia-TrujilloL, Qian C,Martín-BellosoO,McClements DJ. 2013. Influence of particle size on lipid digestion and b-carotene bioaccessibility in emulsions and nanoemulsions. Food Chem. 141, 1475-1480. https://doi.org/10.1016/j.foodchem.2013.03.050

Saneja A, Arora D, Kumar R, Dubey RD, Panda AK, Gupta PN. 2018. Therapeutic applications of betulinic acid nanoformulations. Ann. N.Y. Acad. Sci. 1421, 1-14. https://doi.org/10.1111/ nyas. 13570

Saneja A, Kumar R, Singh A, Dhar Dubey R, Mintoo MJ, Singh G, Mondhe DM, Panda AK, Gupta PN. 2017. Development and evaluation of longcirculating nanoparticles loaded with betulinic acid for improved anti-tumor efficacy. Int. J. Pharm. 531, 153-166. https://doi.org/10.1016/j. ijpharm.2017.08.076

Soica C, Danciu C, Savoiu-Balint G, Borcan F, Ambrus R, Zupko I, Bojin F, Coricovac D, Ciurlea S, Avram S, Dehelean CA, Olariu T, Matusz P. 2014. Betulinic acid in complex with a gamma-cyclodextrin derivative decreases proliferation and in vivo tumor development of non-metastatic and metastatic B164A5 cells. Int. J. Mol. Sci. 15, 8235-8255. https://doi. org/10.3390/ijms 15058235

Thurnher D, Turhani D, Pelzmann M, Wannemacher B, Knerer B, Formanek M, Wacheck V, Selzer E. 2003. Betulinic acid: A new cytotoxic compound against malignant head and neck cancer cells. Head Neck. 25, 732-740. https://doi.org/10.1002/hed.10231 
Vikbjerg AF, Rusig JY, Jonsson $\mathrm{G}, \mathrm{Mu} \mathrm{H}, \mathrm{Xu} \mathrm{X}$. 2006. Strategies for lipase-catalyzed production and the purification of structured phospholipids. Eur. J. Lipid Sci. Technol. 108, 802-811. https:// doi.org/10.1002/ejlt.200600138

Xu T, Pang Q, Wang Y, Yan X. 2017. Betulinic acid induces apoptosis by regulating PI3K/Akt signaling and mitochondrial pathways in human cervical cancer cells. Int. J. Mol. Med. 40, 16691678. http://doi.org/10.3892/ijmm.2017.3163

Yang LJ, Chen Y, Ma Q, Fang J, He J, Cheng YQ, Wu QK. 2010. Effect of betulinic acid on the regulation of Hiwi and cyclin B1 in human gastric adenocarcinoma AGS cells. Acta Pharmacol. Sin. 31, 66-72. https://doi. org/10.1038/aps.2009.177 